\title{
Influence of Curing Conditions on Strength Characteristics of Sea Sand Mortar
}

\author{
Irka Tangke Datu ${ }^{1, a}$, Adiwijaya $^{1, *, b}$, Nur Aisyah Jalali ${ }^{1, c}$, and Khairil ${ }^{1, d}$ \\ ${ }^{1}$ Department of Civil Engineering, Politeknik Negeri Ujung Pandang, Makassar, 90245, Indonesia \\ a irkatd@poliupg.ac.id \\ *, b Corresponding Author: adiwijaya_ali@poliupg.ac.id \\ ${ }^{\mathrm{c}}$ nuraisyahjalali@poliupg.ac.id \\ ${ }^{\mathrm{d}}$ khairil@poliupg.ac.id
}

\begin{abstract}
This present paper aims to investigate strength characteristics of cement mortar using natural sea sand as fine aggregate in different curing conditions. Research was carried out with making mortar mixtures by two types of cement, Portland Composite Cement (PCC) and Pozzolana Portland Cement (PPC) with tap water as mixing water. The characteristics of strength of cement mortar use river sand (RS), sea sand (SS), and washed sea sand (WS) were observed. Further, specimens of cube mortar in size of $50 \mathrm{~mm} \times 50 \mathrm{~mm} \times$ $50 \mathrm{~mm}$ of six mortar mixture series were casted according to Indonesian Standard. At $\mathbf{2 4}$ hours after cube specimens were casted, cube mortar specimens were cured in three curing conditions such as tap water curing (TC), seawater curing (SC) and air curing (AC). After curing at certain period (3-day, 7-day, 14-day, 28-day), cube mortar samples were tested in compressive strength. Results concluded that sea sand aggregate improve characteristic of mortar in compressive strength up to 28 days in all curing conditions, and there was no significant effect of type of curing water (TC and SC) on 28-day strength performance of mortar was obtained. In addition, sea sand could potentially be utilized as an aggregate in production of mortar and/or concrete.
\end{abstract}

Keywords-Sea sand; river sand; curing condition; mortar; strength characteristic

\section{Introduction}

Indonesia is a large archipelago country in the world that consists of 17.580 islands with a coastline of 81.000 $\mathrm{km}$. This geographical condition leads a lot of demand for development of infrastructures, such as ports, road pavements, bridges, etc. As a result, utilization of construction materials such as mortar and concrete is also increased, automatically. Monteiro (2017) in [1] reported that concrete has generally become used material for construction which is about 30 billion tons used annually. Moreover, globally billions of tons of clean water (freshwater) are used a year as mixing water and curing water in the concrete industry [2].
Aggregate is mainly material for mix concrete, which are reached aggregate proportion in concrete approximately $75 \%$ - 80\% [3]. Therefore, properties of aggregate are not only can limit the compressive strength of concrete, but also aggregate properties greatly affect durability of concrete [4]. Also, the properties and chemical content of sand aggregate and water are important characteristics to develop strength and durability of concrete [5].

The utilization of seawater and/or sea sand in the concrete industry is prohibited, cause of the corrosion risk of steel bars in concrete that induced by chloride in seawater or sea sand. Accordingly, if the use of seawater and sea sand is permitted in a mortar and/or concrete production, it will be highly beneficial, it is not only in saving freshwater, but also in the construction costs of concrete production at mainly distant islands. By applicability of seawater as curing water and sea sand as fine aggregate in concrete, it can also reduce emissions of $\mathrm{CO}_{2}$ gas of material transportation [6].

The researches on strength characteristics of mortar and/or concrete utilize seawater and sea sand has been revealed by several studies [6-10]. However, the effect of various curing conditions on the strength of sea sand mortar is not thoroughly investigated. In present study, strength characteristics of natural sea sand mortar were evaluated. The influence of types of cement and curing conditions on the strength of sea-sand mortar are discussed. This paper also addresses the evaluation of critical chloride that may occur corrosion possibility of steel bars in sea sand mortar and/or sea sand concrete. 


\section{Experimental Methodology}

\section{A. Materials}

Two types of cement were used in this study such as Portland Composite Cement (PCC) and Pozzolana Portland Cement (PPC), specified Indonesian Standard (SNI). Table 1 describes the chemical properties of cement that were measured by Scanning Electron Microscopy Energy Dispersive X-Ray Spectroscopy (SEM-EDS), whereas the physical properties of fine aggregate are depicted in Table 2.

In this study, sea sand (natural sea-sand) was utilized as fine aggregate. Sea sand was obtained on seaside of Podang Podang Ca'di Island, district of Pangkajene Kepulauan, province of South Sulawesi which was taken on tidal zone. Further, seawater (natural seawater) as curing water were taken up at the middle of the sea with location coordinate at latitude of $04^{\circ} 53^{\prime} 58,50^{\prime \prime}$ and $119^{\circ} 21^{\prime} 46,82^{\prime \prime}$ longitude. The constituents of natural sea sand aggregate and seawater curing water were used are shown in Table 3 and Table 4, respectively. Both natural sea sand and natural seawater were acquired under dry season in July.

Table 1. Chemical properties of cement

\begin{tabular}{|c|c|c|}
\hline \multirow{2}{*}{ Ingredient } & \multicolumn{2}{|c|}{ Composition (\%) } \\
\cline { 2 - 3 } & PCC & PPC \\
\hline Specific gravity & 2.984 & 2.986 \\
\hline $\mathrm{Na}_{2} \mathrm{O}$ & 0,22 & 1,41 \\
\hline $\mathrm{MgO}$ & 0,67 & 2,17 \\
\hline $\mathrm{Al}_{2} \mathrm{O}_{3}$ & 4,01 & 8,08 \\
\hline $\mathrm{SiO}_{2}$ & 12,34 & 18,61 \\
\hline $\mathrm{SO}_{3}$ & 4,03 & 3,72 \\
\hline $\mathrm{K}_{2} \mathrm{O}$ & 1,22 & 1,81 \\
\hline $\mathrm{CaO}$ & 74,73 & 59,58 \\
\hline $\mathrm{TiO}$ & 0,16 & 0,15 \\
\hline $\mathrm{MnO}$ & 0,17 & - \\
\hline $\mathrm{FeO}$ & 2,45 & 4,47 \\
\hline
\end{tabular}

Table 2. Physical properties of fine aggregate

\begin{tabular}{|l|c|c|}
\hline \multirow{2}{*}{ Physical properties } & \multicolumn{2}{|c|}{ Fine Aggregate } \\
\cline { 2 - 3 } & River sand & Sea sand \\
\hline Moisture content (\%) & 5.56 & 3.06 \\
\hline Clay lumps (\%) & 5.42 & 0.92 \\
\hline Fineness modulus & 1,73 & 2.26 \\
\hline Density (Kg/ltr) & 1.40 & 1.70 \\
\hline Specific gravity, SSD & 2.59 & 2.60 \\
\hline Water absorption (\%) & 4.37 & 2.00 \\
\hline
\end{tabular}

Table 3. Chemical composition of sea sand

\begin{tabular}{|c|c|c|c|c|c|}
\hline \multicolumn{6}{|c|}{ Chemical composition $(\mathrm{Mg} / \mathrm{Kg})$} \\
\hline $\mathrm{Cl}^{-}$ & $\mathrm{SO}_{4}^{2-}$ & $\mathrm{Ca}^{2+}$ & $\mathrm{Mg}^{2+}$ & $\mathrm{K}^{+}$ & $\mathrm{Na}^{+}$ \\
\hline 290 & $<50$ & 592882 & 9165 & $<50$ & 5455 \\
\hline
\end{tabular}

Table 4. Chemical composition of seawater

\begin{tabular}{|c|c|c|c|c|c|c|}
\hline \multirow{2}{*}{$\mathrm{pH}$} & \multicolumn{5}{|c|}{ Chemical composition (ppm) } \\
\cline { 2 - 7 } & $\mathrm{Cl}^{-}$ & $\mathrm{SO}_{4}^{2-}$ & $\mathrm{Ca}^{2+}$ & $\mathrm{Mg}^{2+}$ & $\mathrm{K}^{+}$ & $\mathrm{Na}^{+}$ \\
\hline 7,99 & 23340 & 910 & 583 & 302 & 356 & 7330 \\
\hline
\end{tabular}

\section{B. Mixture Series of Mortar}

Six mortar series were investigated in this research as pointed out in Table 5. Three kinds of fine aggregate were prepared as well as river sand (RS), natural sea sand (SS), and washed sea sand (WS) which washed by tap water (freshwater). Mixture series were produced by two cement types of PCC cement and PPC cement that defined as PCC mortar (CM) and PPC mortar (PM), respectively. Three types of curing condition such as tap water curing (TC), seawater curing (SC) and air curing (AC) were selected as curing condition. Mix proportion of mortar specimens was designed according to Indonesian Standard as depicted in Table 6 [11].

Table 5. Mixture series of mortar

\begin{tabular}{|c|c|c|c|c|c|}
\hline \multirow{2}{*}{ Mixtures } & \multirow{2}{*}{ Cement } & \multirow{2}{*}{ Fine aggregate } & \multicolumn{3}{|c|}{ Curing conditions } \\
\hline & & & $\mathrm{TC}$ & $\mathrm{SC}$ & $\mathrm{AC}$ \\
\hline CM-RS & \multirow{3}{*}{ PCC } & River sand & $\mathrm{v}$ & v & v \\
\hline CM-SS & & Sea-sand & $\mathrm{v}$ & $\mathrm{v}$ & $\mathrm{v}$ \\
\hline CM-WS & & Washed sea-sand & $\sqrt{ }$ & v & v \\
\hline PM-RS & \multirow{3}{*}{ PPC } & River sand & $\sqrt{ }$ & $\sqrt{ }$ & $\sqrt{ }$ \\
\hline PM-SS & & Sea-sand & $v$ & $\mathrm{v}$ & $v$ \\
\hline PM-WS & & Washed sea-sand & $v$ & $\mathrm{v}$ & v \\
\hline
\end{tabular}

TC = Tap water curing; $\mathrm{TC}=$ Seawater curing; $\mathrm{AC}=$ Air curing $\sqrt{ }=$ It was tested at curing age of 3-day, 7-day, 14-day, and 28-day

Table 6. Mix proportion of mortar

\begin{tabular}{|c|c|c|c|c|c|c|}
\hline \multirow{2}{*}{ Material } & \multicolumn{6}{|c|}{ Mixture proportion (Gram) } \\
\cline { 2 - 7 } & CM-RS & CM-SS & CM-WS & PM-RS & PM-SS & PM-WS \\
\hline PCC & 500 & 500 & 500 & - & - & - \\
\hline PPC & - & - & - & 500 & 500 & 500 \\
\hline RS & 1375 & - & - & 1375 & - & - \\
\hline SS & - & 1375 & - & - & 1375 & - \\
\hline WS & - & - & 1375 & - & - & 1375 \\
\hline Tap water & 287.5 & 287.5 & 287.5 & 287.5 & 287.5 & 287.5 \\
\hline
\end{tabular}




\section{Test Methods}

Mortar cube specimens in size of $50 \mathrm{~mm}$ x $50 \mathrm{~mm}$ x $50 \mathrm{~mm}$ for each mixture were produced for compressive strength. 24 hours after casted, mortar specimens were cured in tap water curing (TC), seawater curing (SC) and air curing (AC) as curing conditions. All of cured mortar specimens were placed in indoor building at room temperature of approximately $25^{\circ} \mathrm{C}$. After at a certain curing period for 3 days, 7 days, 14 days, and 28 days in TC, SC, and AC, cube mortar specimens were tested in compressive strength in according to Indonesian Standard (SNI 03-6825-2002) [11]. Then, the average compressive strength of three mortar specimens for each mixture in a certain period were determined as strength of mortar specimens.

In this study, the evaluation of potential corrosion of steel bars reinforcement in concrete was analyzed by total chloride content in sea sand. The actual chloride of sea sand aggregate in concrete is estimated by equation:

$$
\mathrm{Cl}^{-} \text {in concrete }=\mathrm{Cl}^{-} \text {sea sand } \mathrm{X} \text { Content sea sand }
$$

The corrosion possibility of steel bars in concrete due to induced by chloride in sea sand aggregate was evaluated based on critical chloride threshold which could cause initial corrosion of steel reinforcement. Some previous research findings were stated that the critical chloride threshold for corrosion occurrence is generally limited by $0.19 \%-2.0 \%$ by weight of binder [12]. However, this present study, the evaluation of critical chloride threshold was determined by based on three literature reviews such as that was $0.4 \%$ by weight of binder (Browne, 1980; Mohammed, 2006), limitation of chloride $1.2 \mathrm{~kg} / \mathrm{m} 3$ in concrete (JSCE Standard, 2010), and acceptable chloride percentage of $0.075 \%$ by weight of sand [13-16].

Further, the amount of chloride in $1 \mathrm{~m} 3$ of concrete were calculated by using some standard codes and assumption of data such as unit weight of fresh concrete is to be $2483 \mathrm{Kg} / \mathrm{M}^{3}$ according with Indonesian standard [17]. The ratio sea sand to total aggregate (s/a) was assumed 0.48. Moreover, water content in simulated concrete mixture was defined $190 \mathrm{Kg} / \mathrm{M}^{3}$ which maximum water cement ratio (w/c) of simulated concrete was designed by 0.45 as specified Indonesian
Standard for concrete structures requirement in marine environmental [18]. Based on aforementioned data, simulated concrete proportion was used in order to evaluate critical chloride threshold is shown in Table 7.

Table 7. Simulated concrete proportion for chloride analysis

\begin{tabular}{|c|c|c|c|c|c|}
\hline \multirow{2}{*}{ w/c } & \multirow{2}{*}{ s/a } & \multicolumn{4}{|c|}{$\begin{array}{c}\text { Simulated concrete mixture } \\
\text { proportion }\left(\mathrm{Kg} / \mathrm{M}^{3}\right)\end{array}$} \\
\cline { 3 - 6 } & & Water & Cement & Sea sand & $\begin{array}{c}\text { Coarse } \\
\text { Aggregate }\end{array}$ \\
\hline 0.45 & 0.48 & 190 & 422 & 498 & 1373 \\
\hline
\end{tabular}

\section{Results and Discussion}

\section{A. Charateristic of Mortar}

The mortar characteristics such as normal consistency and setting time of six mixtures using two with two types of cement and three types of sand are depicted in Table 8. The results were observed that characteristic of normal consistency was not significant difference in all mortar mixtures. The consistency result of all mortar mixtures in ranging from to $110 \%-120 \%$ met mortar specification according with Indonesian standard [19]. Based on test result, it suggests that consistency of mortar mixed by river sand (RS), sea sand (SS), and washed sea sand (WS) is not affected by type of cement (PCC and PPC) and type of sand (SR, SS, and WS).

Furthermore, the different results of mortar mixtures were found in initial setting time. Test result pointed out that the initial setting time of sea sand mortar with PCC (CM-SS) and washed sea sand mortar with PPC (PM$\mathrm{SS})$ were enhanced compared to river sand mortar for both of PCC river sand mortar (CM-RS) and PPC river sand mortar (PM-RS). While, no significance difference was obtained in initial setting time of PCC sea sand mortar (CM-SS) and PCC washed sea sand mortar (CM-WS). This obtained result was the same as for both of PCC sea sand mortar (PM-SS) and PPC washed sea sand mortar (PM-WS). This finding expresses that SS and WS retards initial setting time of CM and PM mortar. This tendency is contradictory result by previous study that uses sea sand concrete [20].

The effect of cement type on initial setting time of mortar was also gained. The initial setting of PM-SS 
and PM-WS was longer than that of initial setting time of CM-SS and CM-WS, respectively. In contrast, when PPC cement and RS used in production of mortar, initial setting time of PM-RS was more rapid instead of CMRS. It indicates that hydration reaction of PPC semen is slightly more rapid than PCC cement as cement mortar is generated by RS fine aggregate. This phenomenon is expected due to the effect of the chemical composition of cement, especially compound of Aluminum Oxide $\left(\mathrm{Al}_{2} \mathrm{O}_{3}\right)$ and Calcium Oxide $(\mathrm{CaO})$ of PPC cement as pointed out in Table 1, which are both of compound contributes in a heat of cement hydration and hydration reaction of cement.

Table 8. Characteristics of mortar sample

\begin{tabular}{|c|c|c|}
\hline \multirow{2}{*}{ Mixtures } & \multicolumn{2}{|c|}{ Characteristic of mortar } \\
\cline { 2 - 3 } & Consistency $(\%)$ & Initial setting (minute) \\
\hline CM-RS & 114 & 90 \\
\hline CM-SS & 115 & 100 \\
\hline CM-WS & 114 & 105 \\
\hline PM-RS & 114 & 65 \\
\hline PM-SS & 115 & 110 \\
\hline PM-WS & 113 & 120 \\
\hline
\end{tabular}

\section{B. Strength Development}

The strength development of cube mortar specimens of six mixture series in curing condition of TC, SC, and AC for a curing period of 3-day, 7-day, 14-day, and 28day is shown in Figure 1. The test result denotes that all mortar specimens in tap water curing (TC) and seawater curing (SC) was increased in compressive strength with an increasing curing period of up to 28 days as described in Figure 1(a) and Figure 1(b). On the other hand, Figure 1(c) exhibits compressive strength up to 28 days of mortar specimens cured in air curing (AC). This phenomenon is clear that cement in mortar is obstructed to undergone hydration reaction due to lack of water, thus mortar in AC is not perfectly developed in strength.

\section{Effect of Sea Sand and Cement Type}

The effect of sea sand aggregate, SS, and WS on the strength of mortar is represented in the ratio of mortar compressive strength as the strength ratio of SS to RS (SS/RS), strength ratio of SS to WS (SS/WS), and strength ratio of WS to RS (WS/RS) in both PCC cement $(\mathrm{CM})$ and PPC cement (PM) as depicted in Figure 2.

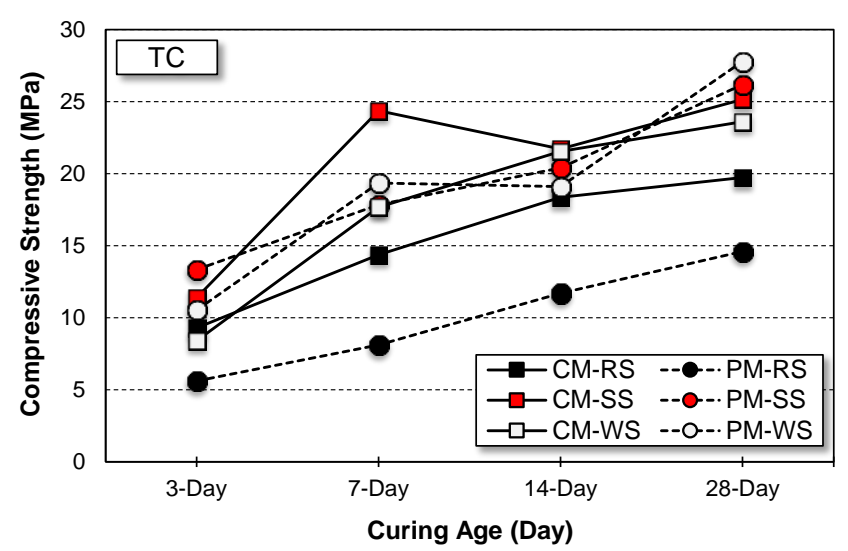

(a) Strength development of mortar in TC

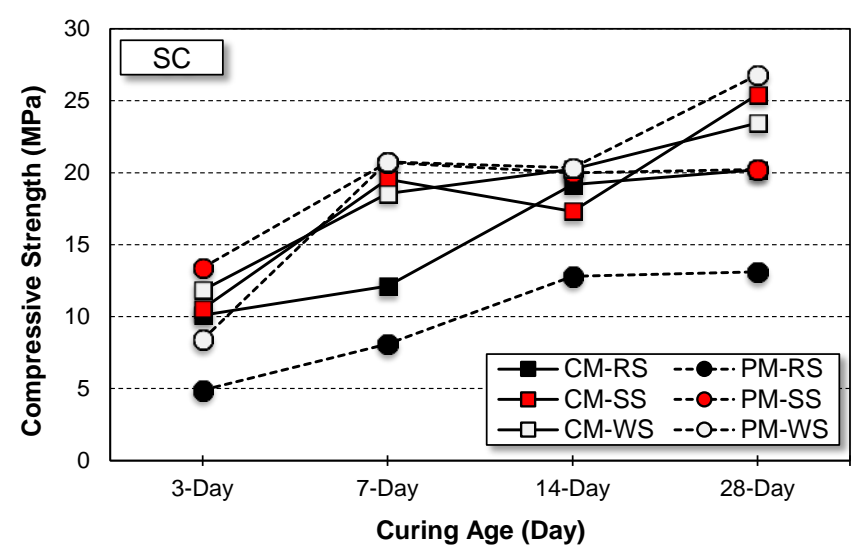

(b) Strength development of mortar in SC



(c) Strength development of mortar in AC

Figure 1. Strength development of mortar

Results show that the ratio strength of all mortar specimens at 28 days curing age was above the line of equality (ratio $>1$ ). It was clear that the compressive strength of SS mortar and WS mortar was higher than that of the strength of RS mortar. Even though, strength ratio of SS/WS for PPC mortar was slightly lower equality line. Based on observation results, it may be generally concluded that strength ratio was more than 
one for all mortar specimens. The results showed that sea sand as fine aggregate can improve the compressive strength of mortar up to 28 days. The enhancement in compressive strength of SS mortar and WS mortar is predicted to be owing to the effect of aggregate gradation of sea sand, which is fineness modulus of sea sand is higher than river sand as shown in Table 2. This prediction is also proven by strength ratio of washed sea sand mortar to river sand mortar (WS/RS) that was greatly increased in ratio of strength. Thus, development strength of SS mortar and WS mortar is more affected by gradation of aggregate compared with chloride effect of sea sand mortar. The largest strength ratio of SS mortar to RS mortar is attained in air curing, AC. It means, that strongly positive effect of sea sand in increasing strength of mortar is achieved in air curing compared with in water curing, TC and SC.

The effect of cement kind on the strength performance of mortar was also found as described in Figure 3. It was observed that 28 days strength of PCC river sand mortar (CM-RS) specimen was rather upper than that of strength of PCC river sand mortar (PM-RS) in all curing. Nevertheless, the strength characteristic of sample of CM-SS mortar and CM-WS mortar were nearly the same as CM-SS mortar and CM-WS mortar in strength-28 days. The result may be suggested that there is no significant influence of cement type of PCC and PPC on the 28-day compressive strength of sea sand mortar. In other words, strength of SS mortar and WS mortar is not significantly affected by cement type, PCC and PPC.

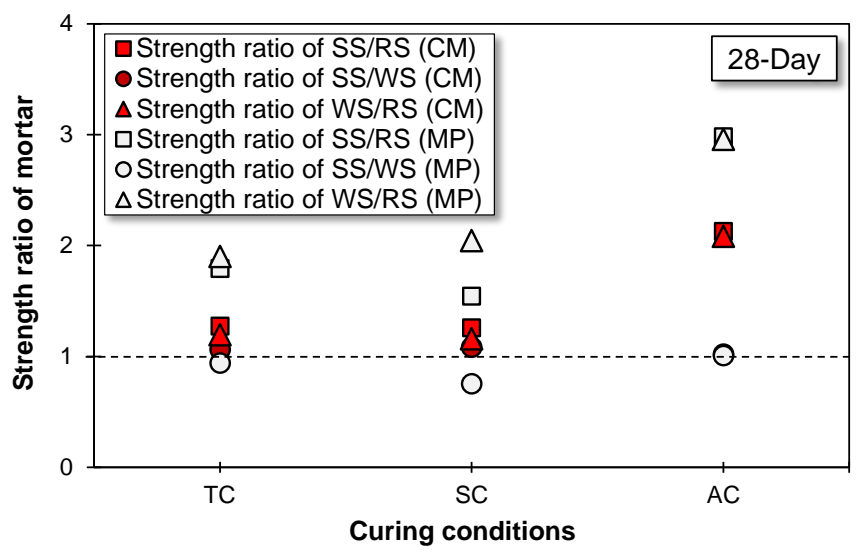

Figure 2. Strength ratio of SS-mortar to RS-mortar

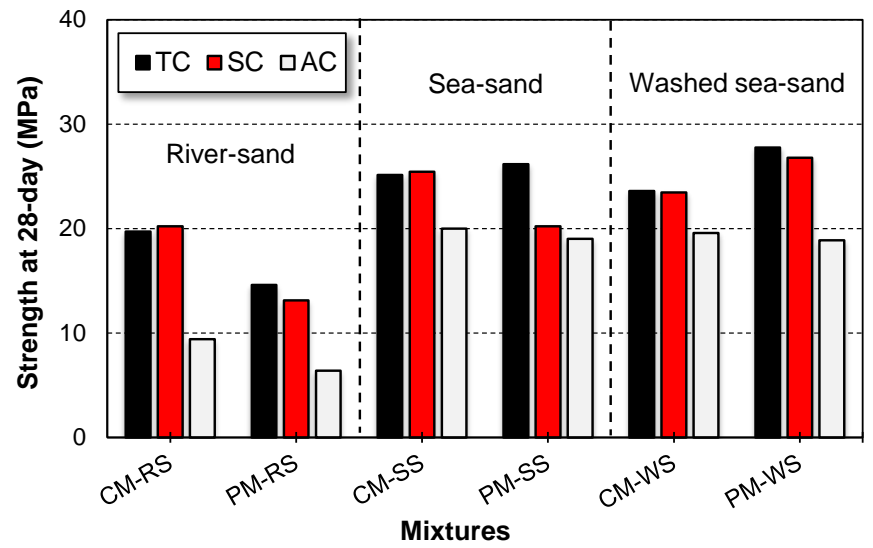

Figure 3. Strength performance of mortar at 28 days

\section{Effect of Curing Conditions}

It is well-known, the items of importance related to concrete quality; water to cement ratio, cement content, mixing, curing, cracking and other aspects. Curing is the largest factor affecting the strength and durability of mortar or concrete [21]. The influence of the curing condition on the compressive strength of RS mortar, SS mortar, and WS mortar at 28 days curing period was also obtained in this study. Based on the observation result, it represents that strength of all mortar specimens in cured air (AC) were significantly lower than that of mortar strength in cured water, TC and SC as shown in Figure 3 . The similarity finding is also revealed by a previous study with seawater-mixed mortar specimen [22]. This tendency occurs owing to the cement hydration process is not normally taking place. As known, the hydration process and cement reaction require enough water for hydration in order to produce Calcium Silicate Hydrate (C3S) as the main compound that forms the strength of mortar and concrete.

The influence of curing water type on the strength characteristic of mortar was also found. The 28-days compressive strength of all mortar specimens in TC and SC was closely line of equality as described in Figure 4, even though for PM-SS specimen on 28 days strength of mortar in TC was slightly higher than that of 28 days mortar strength in SC. Accordingly, this result can generally be expressed that there is no have significant effect of type of curing water on compressive strength up to 28 days in all mortar mixture types. In other words, compressive strength up to 28 days of RS mortar, SS mortar, WS mortar is not affected by type of 
curing water, TC and SC. The same phenomenon is also stated by previous researchers such as Adi (2014) [23] with seawater mixed OPC and seawater mixed Fly Ash concrete [23-24].

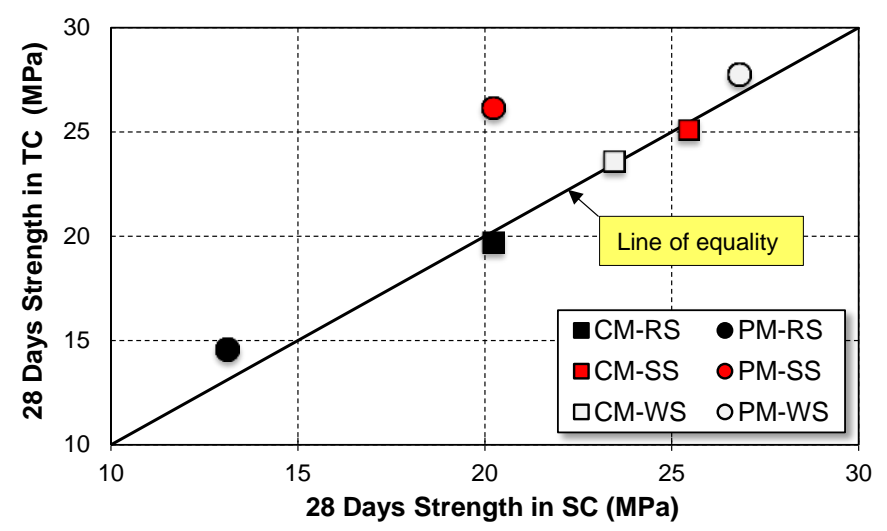

Figure 4. Strength of mortar in SC vs mortar in TC

The analysis of the amount of chloride and critical chloride threshold by weight of sea sand in $1 \mathrm{~m}^{3}$ of simulated concrete mixture was calculated by based on data in Table 7 and Eq. 1. Table 8 shows the chloride analysis result of simulated concrete, whether sea sand aggregate were used in concrete production, then the total chloride content in concrete is still below the chloride threshold which may cause the potential for initial corrosion of steel bars in concrete as stated by the literature review [13-16]. Thus, it may be concluded that sea sand concrete is no have risk against chlorideinduced corrosion possibility. In other words, the corrosion possibility of steel bars due to chloride in sea sand concrete may be ignored. Thus, sea sand may be utilized as an aggregate in mortar or concrete. This recommendation has also been proposed by previous study [6], [25].

Table 8. Analyzed result of chloride in simulated concrete

\begin{tabular}{|c|c|c|}
\hline \multirow{2}{*}{$\begin{array}{l}\text { Critical chloride analysis } \\
\text { based on literature review }\end{array}$} & \multicolumn{2}{|c|}{$\begin{array}{l}\text { Amount of chloride in concrete } \\
\left(\mathrm{Kg} / \mathrm{M}^{3} \text { concrete }\right)\end{array}$} \\
\hline & $\begin{array}{c}\text { Calculated } \\
\text { chloride by } \\
\text { using sea sand }\end{array}$ & $\begin{array}{c}\text { Critical } \\
\text { chloride } \\
\text { threshold }\end{array}$ \\
\hline $\begin{array}{l}\text { By weight of binder } \\
\text { [13-14] }\end{array}$ & \multirow{3}{*}{0.144} & 1.688 \\
\hline By JSCE standard [15] & & 1.200 \\
\hline By weight of sand [16] & & 0.374 \\
\hline
\end{tabular}

\section{Conclusion}

The effect on strength characteristics of sea sand mortar under different curing condition has been revealed, some following conclusions can be drawn:

1. Compressive strength up to 28 days of sea sand mortar and washed sea sand mortar was higher than that of river sand mortar in all curing conditions. It means that sea sand aggregate improve characteristic of mortar in compressive strength.

2. There was no significantly different on strength performance up to 28 days of CM mortar and PM mortar used SS and WS sand. It implies that compressive strength of SS mortar and WS mortar is not seriously affected by cement type, PCC and PPC.

3. There was no have significant effect of type of curing water such as TC and SC on 28-day strength performance of mortar in all mixtures. Besides, result showed that 28 days mortar strength in air curing was rather lower than that of mortar in water curing for all mortar mixture specimens.

4. Sea sand mortar and/ or concrete was not has probable risk against corrosion occurrence due to induced by chloride. In other word, the possibility of chloride-induced reinforcing bars corrosion of sea sand mortar and/or concrete can be ignored. Thus, sea sand could potentially be utilized as an aggregate in mortar and/or concrete production.

\section{Acknowledgement}

The authors would like to sincerely thank Mr. Indra Karuniawan and Mrs. Syesaria Taurina, who have graduated from Department of Civil Engineering of Politeknik Negeri Ujung Pandang and shared their experimental work for completing this paper.

\section{References}

[1] Paulo J.M. Monteiro, Sabbie A. Miller, A. Horvath, 2017. "Towards sustainable concrete," Nature Mat. Vol.16, pp.698699.

[2] N. Otsuki, D. Furuya, S. Saito, and Y. Tadokoro, 2011. "Possibility of sea water as mixing water in concrete," Proceeding of 36th Conference on Our world in Concrete \& Structures, Singapore.

[3] S. Hasdemir, A. Tugrul, and M. Y1lmaz, 2016. "The effect of natural sand composition on concrete strength," Construction and Building Materials, Vol.112, pp.940-948. 
[4] A.M. Neville and J.J. Brooks, Concrete Technolgy, 2nd Edition. 2011. London: Prentice Hall, pp. 40-41.

[5] T. Dhondy, A. Remennikov, M.ASCE, and M. Neaz Sheikh, 2020. "Properties and application of sea sand-seawater concrete," Journal of Materials in Civil Engineering, vol.32 (12), pp.1-11.

[6] K. Katano, N. Takeda, Y. Oshozaki, and K. Iriya, 2013. "Properties and application of concrete made with seawater and un-washed sea sand," Proceeding of 3rd International Conference on Sustainable Construction Materials and Technologies, Kyoto-Japan.

[7] S. Ponnada, VR Sankar Cheela, and SSSV Gopala Raju, "Investigation on mechanical properties of composite concrete containing untreated sea sand and quarry dust for 100\% replacement of fine aggregate," Material Today: Proceedings (xxx) [ $3^{\text {rd }}$ International Conference on Innovative Technologies for Clean and Sustainable Development, India, 2020], in press.

[8] K. Thunga, and T. Venkat Das, "An Experimental investigation on concrete with replacement of treated sea sand as fine aggregate," Material Today: Proceedings (xxx) [1 $1^{\text {st }}$ International Conference on Advanced Lightweight Materials and Structures, India, 2020], in press.

[9] I.S. Fuad, B. Azmawi, dan Hermawan, 2015. "Pengaruh penggunaan pasir sungai dengan pasir laut terhadap kuat tekan dan lentur pada mutu beton K-225 (The effect of using river sand with sea sand on the compressive strength and bending strength on the concrete quality of K225) ," Jurnal Desiminasi Teknologi, Vol. 3 (1), pp.31-39.

[10] Peiran Li, Wengui Li, Tao Yu, Fulin Qu, and Vivian W.Y. Tam, 2020. "Investigation on early-age hydration, mechanical properties and microstructure of seawater sea sand cement mortar," Construction and Building Materials, Vol.249, pp.112.

[11] Standar Nasional Indonesia, Metode Pengujian Kekuatan Tekan Mortar Semen Portland untuk Pekerjaan Sipil (SNI 03-68252002), 2002. Jakarta: BSN.

[12] Ueli Angst, Bernhard Elsener, Claus K. Larsen, and Øystein Vennesland, 2009. "Critical chloride content in reinforced concrete-A review," Cement and Concrete Research, Vol.39, pp.1122-1138.

[13] R.D. Browne, 1980. "Mechanism of corrosion of steel in concrete in relation to design, inspection and repair offshore and coastal structures, performance of concrete in marine environment," ACI SP 65, pp.169-204.

[14] T.U. Mohammed and H. Hamada, 2006. "Corrosion of steel bars in concrete with various steel surface conditions," ACI Materials Journal, Vol. 103 (4), pp.233-242.
[15] Japan Society of Civil Engineers, Standard Specifications for Concrete Structures-2007 "Design”, 2010. Japan: JSCE.

[16] M. Karthikeyan and V. Nagarajan, 2017. "Chloride analysis of sea sand for making concrete (Short Communication)," Natl. Acad. Sci. Lett., Vol. 40, pp.29-31.

[17] Standar Nasional Indonesia, Cara Uji Berat Isi, Volume Produksi Campuran dan Kadar Udara Beton (SNI 1973:2008), 2008. Jakarta: BSN.

[18] Standar Nasional Indonesia, Tata Cara Pembuatan Rencana Campuran Beton Normal (SNI 03-2834:2000), 2000. Jakarta: BSN.

[19] Standar Nasional Indonesia, Spesifikasi Mortar untuk Pekerjaan Pasangan (SNI 03-6882-2002), 2002. Jakarta: BSN.

[20] AV Sharanova, AO Tovpinets, and MA Dmitrieva, 2019. "Application of sea sand for 3D concrete printing," IOP Conference Series: Mater. Sci. Eng., vol. 597 (012033), pp.1-4, April 2019. $16^{\text {th }}$ International Conference of Students and Young Scientists "Prospects of Fundamental Sciences Development, Tomsk-Russia.

[21] P.A.M. Basheer, S.E. Chidiac, and A.E. Long, 1995. "Predictive models for deterioration of concrete structures," Construction and Building Materials, Vol.10 (1), pp.27-37.

[22] Adiwijaya dan I.T. Datu, 2018. "Pengaruh air laut sebagai air pencampur dan air perawatan pada karakteristik pasta semen dan mortar (Effect of seawater as mixing water and curing water on the characteristics of cement paste and mortar)," Journal INTEK, Vol. 5 (1), pp.28-33.

[23] Adiwijaya, H. Hamada, Y. Sagawa, and D. Yamamoto, 2014. "Effects of mineral admixtures on strength characteristics of concrete mixed with seawater," Proceeding of The 6th International Conference of Asian Concrete Federation, Seoul, pp. 925-930.

[24] Adiwijaya, H. Hamada, Y. Sagawa, and D. Yamamoto, 2014. "Effects of Mix Proportion and Curing Condition on Carbonation of Seawater-Mixed Concrete," Proceeding of The Conference for Civil Engineering Jointly held with The 7th ASEAN Civil Engineering Conference, Bandung-Indonesia, pp. 64-69.

[25] S. Sidhardhan, S.J. Sheela, and J.S. Meylin, 2017. "Study on sea sand as a partial replacement for fine aggregate," Journal of Advances in Chemistry, vol.1 3 (4), pp.6166-6171. 